\title{
FERTILIZER MANAGEMENT FOR MAXIMIZING SOYBEAN (Glycine $\max$ L.) PRODUCTION IN SALINE AGRO-ECOSYSTEM OF BARGUNA
}

\author{
M.J. Hasan ${ }^{1}$, S. Ahmed ${ }^{2}$, M.A. Rahman ${ }^{1}$ and S.C. Samanta ${ }^{2}$ \\ ${ }^{1}$ MS student, Department of Agronomy, Patuakhali Science and Technology University, Dumki, Patuakhali- \\ 8602 \\ ${ }^{2}$ Professor, Department of Agronomy, Patuakhali Science and Technology University, Dumki, \\ Patuakhali-8602 \\ "Corresponding E-mail: sultanpstu@yahoo.com
}

(Received: 24 July 2019, Accepted: 24 October 2019)

Keywords: Fertilizer dose, soybean, saline eco-system, yield

\begin{abstract}
An experiment was conducted at saline agro-ecosystem of Burir Char Union, Barguna District during January to June 2018, with a view to find out the fertilizer management for maximizing soybean (Glycine max L.) production in saline agro-ecosystem was laid out in randomized complete block design consisted of three varieties of soybean and four levels of fertilizer doses with three replications. Three varieties of soybean viz. BARI Soybean-5, BARI Soybean-6 and Binasoybean-3 and four fertilizer levels viz. $\mathrm{T}_{1}=25-30-45-10-1.0-1.0 \mathrm{kgha}^{-1}$ N-P-K-S-Zn-B (Soil test based fertilizer); $T_{2}=30-40-60-12-2.0-1.0 \quad \mathrm{kgha}^{-1} \quad$ N-P-K-S-Zn-B (Fertilizer recommendation guide, 2012); $\mathrm{T}_{3}=40-20-15-0-0-0 \mathrm{kgha}^{-1} \mathrm{~N}-\mathrm{P}-$ $\mathrm{K}-\mathrm{S}-\mathrm{Zn}-\mathrm{B}$ (Farmers practices); $\mathrm{T}_{4}=$ Control native fertility were considered which placed in a factorial randomized block design. The variety had significant influence on plant height, branches plant ${ }^{-1}$, number of filled pods plant ${ }^{-1}$, number of unfilled pods plant ${ }^{-1}$, seed yield plant ${ }^{-1}$, seed yield ( $\mathrm{t}$ ha $\left.{ }^{-1}\right)$, stover yield $\left(\mathrm{t} \mathrm{ha}^{-1}\right)$. BARI Soybean-6 performed better than the other two varieties. The fertilizer doses had significant influence on plant height, branches plant ${ }^{-1}$, number of filled pods plant ${ }^{-1}$, number of unfilled pods plant ${ }^{-1}$, seed yield plant ${ }^{-1}, 100$-seed weight, seed yield $\left(t a^{-1}\right)$, stover yield ( $\mathrm{t}$ ha-1 $)$. Fertilizer doses 25-30-45-10-1.0-1.0 kgha $^{-1}$ N-P-K-S-Zn-B (Soil test based fertilizer) gave the maximum yield. The interaction between variety and fertilizer doses $\mathrm{V}_{2} \mathrm{~T}_{1}$ (BARI Soybean- 6 and 25-30-4510-1.0-1.0 $\mathrm{kgha}^{-1}$ N-P-K-S-Zn-B) produced the maximum yield SO, the variety BARI Soybean-6 with fertilizer dose 25-30-45-10-1.0-1.0 $\mathrm{kgha}^{-1}$ $\mathrm{N}-\mathrm{P}-\mathrm{K}-\mathrm{S}-\mathrm{Zn}-\mathrm{B}$ could be suitable combination for higher yield of soybean in saline agro ecosystem of Barguna.
\end{abstract}

\section{Introduction}

Soybean (Glycine max L.) is an important global legume crop that grows in the tropical, subtropical and temperate climates. Its seed contains about $40 \%$ protein and $20 \%$ oil, provides approximately $60 \%$ of the world supply of vegetable protein and 30\% of the oil (Fehr, 1989). Soybean is an important source of human dietary protein with an average of 40\% content, 30\% carbohydrate and oil content of 20\% (Adu-Dapaah et al., 2004; MoFA and CSIR, 2005). As a grain legume, it is gaining important position in the agriculture of tropical countries including Bangladesh. Now, soybean producing areas are Barisal, Bhola, Faridpur, Patuakhali, Meherpur, Jessore, Rangpur, Kurigram, Thakurgaon, Tangail, Mymensingh, Jamalpur, Chandpur, Feni, Noakhali and Laxmipur (Chowdhury et al., 2013). Farmers of this area generally grow local variety of soybean with no or limited application of fertilizer. For this reason, the yield of soybean in this 
Hasan et al.

region is much below than that of potential yield level. Balanced fertilization can play a major role to enhance the present yield level. Although soybean can fix atmospheric $\mathrm{N}$ in soil which is necessary for better yield. Fertilizer recommendation solely based on crop response data often fails to show economic viability. Since the application of optimum dose of fertilizer is important for increasing the yield of soybean, but very limited information in this regard is available in Bangladesh. The present study was undertaken to find out salt tolerant variety and develop a fertilizer management practices for coastal area.

\section{Materials and Methods}

The experiment was conducted at Saline agro-ecosystem of Barguna during January to June 2018 with geographical location of $22.1508 \mathrm{~N}$ latitude and $90.1264 \mathrm{E}$ longitude at the elevation of $1.5 \mathrm{~m}$ above the sea level. Before conducting the experiment the initial composite soil sample $(0-15 \mathrm{~cm})$ were collected from the experiment plot. The land was clay loam in texture having a soil $\mathrm{pH}$ value of 7.9, moderate in organic matter content. Soil characteristics of the experimental plot have been presented in Table (1). The experiment was laid out in a factorial randomized complete block design (RCBD) with 3 replications. The variety BARI Soybean -5, BARI Soybean-6 and Bina soybean-3 was used as test crops. The unit plot size was $4 \mathrm{~m}$ Y $3 \mathrm{~m}$.Spacing $30 \mathrm{~cm} \Psi 10 \mathrm{~cm}$. Four fertilizer treatments viz.; $\mathrm{T}_{1}$ : 25-30-45-10-1.0-1.0 $\mathrm{kgha}^{-1} \mathrm{~N}-\mathrm{P}-\mathrm{K}-\mathrm{S}-\mathrm{Zn}-\mathrm{B}$ (Soil test based fertilizer)), $\mathrm{T}_{2}$ : 30-40-60-12-2.0-1.0 $\mathrm{kgha}^{-1}$ N-P-K-S-Zn-B (Fertilizer recommendation guide, 2012) $\mathrm{T}_{3}$ : 40-20-15-0-0-0 kgha-1 N-P-K-S-Zn-B (Farmers practices) and $\mathrm{T}_{4}$ : native fertility (control) were applied Half of urea and entire amount of other fertilization was applied as basal during final land preparation and the remaining half of urea was applied as top-dressed after 21 days of sowing. First irrigation was applied after 35 days after sowing before flowering and the second irrigation was applied at pod formation stage. Different intercultural operations and plant protection measures was taken as and when necessary to raise healthy crop. Data were collected on an individual plant basis and seed yield plant ${ }^{-1}(\mathrm{~g})$ was estimated after cleaning and proper drying. Plot yield was recorded $\left(3 \mathrm{~m}^{2}\right.$ from each plot) and then converted to $t \mathrm{ha}^{-1}$. All data were statistically analyzed using 'Analysis of variance technique' with the help of MSTAT- $\mathrm{C}$ computer program and the mean difference were compared by Duncan's Multiple Range Test at 5\% level of significance.

Table 1. Chemical properties of soil (0 $-15 \mathrm{~cm}$ depth) collected before cultivation of thecrop in experimental field at Barguna

\begin{tabular}{ll}
\hline Soil properties & Values \\
\hline A. Physical properties & \\
1. Particle size & 19.17 \\
a. Sand (\%) & 54.82 \\
b. Silt (\%) & 26.01 \\
c. Clay (\%) & Silty clay \\
2. Soil textural class & \\
B. Chemical properties & 7.9 \\
1. Soil pH & $6.34 \mathrm{dS} \mathrm{m}^{-1}$ \\
2. Electrical conductivity & 0.35 \\
3. Organic carbon & 1.42 \\
4. Organic matter & 0.071 \\
5. Total N (\%) & 8.49 \\
6. Available P (ppm) & 0.58 \\
7. Available S ( $\mu \mathrm{g} / 100 \mathrm{~g}$ soil) & 0.18 \\
8. Exchangeable $\mathrm{K}$ & 0.59 \\
9. Boron ( $\mu \mathrm{g} / 100 \mathrm{~g}$ soil) &
\end{tabular}




\section{Plant height}

The effect of variety and different fertilizer treatments on the plant height is presented in Table 2. There were significant variations among variety and treatments. In case of variety the highest plant height $(52.20 \mathrm{~cm})$ was observed in BARI Soybean-6 and shortest plant height $(48.12 \mathrm{~cm})$ in BARI Soybean-5.In case of fertilizer doses, the highest plant height $(51.26 \mathrm{~cm})$ was observed in $\mathrm{T}_{1}$ and shortest plant height $(44.20 \mathrm{~cm})$ in $\mathrm{T}_{4}$. Incase of interaction effect of variety and treatment in Table 3, the highest plant height $(45.67 \mathrm{~cm})$ was observed $\operatorname{inV}_{2} \mathrm{~T}_{2}$ and shortest plant height $(33.58 \mathrm{~cm})$ was observed in $\mathrm{V}_{3} \mathrm{~T}_{4}$. Hasio et al. (1976) stated that plant height is the function of vertically cell enlargement and it is an important morphological character that influenced by growing condition such as plant variety.

\section{Number of filled pods per plant ${ }^{-1}$}

Table 2 showed there was no significant differences in variety but fertilizer treatment had significant effect where the highest number of filled pods plant ${ }^{-1}$ (43.69) was produced in $\mathrm{T}_{1}$ and the lowest number of filled pods plant ${ }^{-1}$ (33.78) in $\mathrm{T}_{4}$ treatment. In case of interaction effect of variety and fertilizer dose (Table 3 ), the highest number of filled pods plant ${ }^{-1}$ (51.33) was produced in $V_{2} T_{1}$ and the lowest number of filled pods splant ${ }^{-1}(23.60) \mathrm{s}$ in $\mathrm{V}_{1} \mathrm{~T}_{4}$. This result was in conformity with the findings of Karte et al. (1983).

Table 2. Effect of variety and fertilizer dose on plant height, seeds pod $^{-1}$, filled pods plant ${ }^{-1}$, 100-seed weight, seed yield and stover yield

\begin{tabular}{|c|c|c|c|c|c|c|}
\hline Treatments & $\begin{array}{l}\text { Plant height } \\
\text { (cm) }\end{array}$ & $\begin{array}{l}\text { Number of } \\
\text { seeds pod } \\
1\end{array}$ & $\begin{array}{l}\text { Number of } \\
\text { filled pods } \\
\text { plant }^{-1}\end{array}$ & $\begin{array}{l}100 \text {-seed } \\
\text { weight } \\
\text { (g) }\end{array}$ & $\begin{array}{l}\text { Seed } \\
\text { yield } \\
\left(\mathrm{t} \mathrm{ha} \mathrm{ha}^{-1}\right)\end{array}$ & $\begin{array}{l}\text { Stover } \\
\text { yield } \\
\left.(\mathrm{t} \mathrm{ha})^{-1}\right)\end{array}$ \\
\hline \multicolumn{7}{|l|}{ Variety } \\
\hline $\begin{array}{l}\text { BARI Soybean- } \\
5\end{array}$ & \multirow{2}{*}{48.12} & $2.44 \mathrm{~b}$ & $38.35 \mathrm{a}$ & $7.92 \mathrm{a}$ & $1.75 \mathrm{ab}$ & $4.63 \mathrm{~b}$ \\
\hline $\begin{array}{l}\text { BARI Soybean- } \\
6\end{array}$ & & $2.68 \mathrm{a}$ & $41.07 \mathrm{a}$ & $7.67 \mathrm{~b}$ & $1.78 \mathrm{a}$ & $4.73 \mathrm{a}$ \\
\hline Binasoybean-3 & 49.11 & $2.43 \mathrm{~b}$ & $36.72 \mathrm{a}$ & $7.42 \mathrm{~b}$ & $1.73 \mathrm{~b}$ & $3.62 \mathrm{c}$ \\
\hline $\operatorname{LSD}_{(0.05)}$ & 5.49 & 0.19 & 6.21 & 1.18 & 0.91 & 1.15 \\
\hline CV (\%) & 3.82 & 9.57 & 8.20 & 14.41 & 2.15 & 12.67 \\
\hline \multicolumn{7}{|l|}{ Fertilizer dose } \\
\hline $\mathrm{T}_{1}$ & 51.26 & $2.50 \mathrm{a}$ & $43.69 \mathrm{a}$ & 8.00 & $1.86 \mathrm{a}$ & $4.98 \mathrm{~b}$ \\
\hline $\mathrm{T}_{2}$ & 47.39 & $2.45 \mathrm{a}$ & $35.69 \mathrm{~b}$ & 8.44 & $1.80 \mathrm{~b}$ & $5.28 \mathrm{a}$ \\
\hline $\mathrm{T}_{3}$ & 46.85 & $2.44 \mathrm{a}$ & $39.02 \mathrm{ab}$ & 7.88 & $1.70 \mathrm{c}$ & $4.98 \mathrm{~b}$ \\
\hline $\mathrm{T}_{4}$ & 44.20 & $2.42 \mathrm{~b}$ & $33.78 \mathrm{~b}$ & 7.66 & $1.65 \mathrm{~d}$ & $3.08 \mathrm{c}$ \\
\hline $\mathrm{LSD}_{(0.05)}$ & 6.34 & 0.23 & 7.50 & 1.36 & 0.05 & 1.33 \\
\hline CV (\%) & 3.82 & 9.57 & 8.20 & 14.41 & 2.15 & 12.67 \\
\hline
\end{tabular}

Common letters do not differ significantly by Duncan's Multiple Range Test at $5 \%$ level of significance

$\mathrm{T}_{1}$ : 25-30-45-10-1.0-1.0 $\mathrm{kgha}^{-1}$ N-P-K-S-Zn-B (Soil test based fertilizer)), $\mathrm{T}_{2}$ : 30-40-60-12-2.01.0 kgha $^{-1}$ N-P-K-S-Zn-B (Fertilizer recommendation guide, 2012) $\mathrm{T}_{3}: 40-20-15-0-0-0 \mathrm{kgha}^{-1}$ $\mathrm{N}-\mathrm{P}-\mathrm{K}-\mathrm{S}-\mathrm{Zn}-\mathrm{B}$ (Farmers practices) and $\mathrm{T}_{4}$ : native fertility (control)

\section{0-seed weight}


Hasan et al.

Significantly highest 1000-seed weight was obtained from BARI Soybean 5. In case of fertilizer treatment, there was no significant difference was found. Butinter action effect of variety and fertilizer dose (Table 3) showed significant where the maximum 100-seed weight $(9.33 \mathrm{~g})$ was obtained from $\mathrm{V}_{1} \mathrm{~T}_{1}$ and $\mathrm{V}_{1} \mathrm{~T}_{2}$ and the lowest 100-seed weight $(7.00 \mathrm{~g})$ from $\mathrm{V}_{3} \mathrm{~T}_{4}$. The present results were in agreement with those of Singh and Singh (1995) who reported that 100-seed weight increased by STB based fertilizer dose over control due to optimum uptake of nutrients.

Table 3. Interaction effects of variety and fertilizer dose on plant height, number of seeds pod $^{-1}$, number of filled pods plant ${ }^{-1}, 100$-seed weight, seed yield and stover yield

\begin{tabular}{|c|c|c|c|c|c|c|c|}
\hline $\begin{array}{l}\text { Variety/ प } \\
\text { Fertilizer dose }\end{array}$ & $\begin{array}{l}\text { Plant } \\
\text { height } \\
\text { (cm) }\end{array}$ & $\begin{array}{l}\text { Number of } \\
\text { seeds pod }{ }^{-1}\end{array}$ & $\begin{array}{l}\text { Number } \\
\text { filled } \\
\text { plant }^{-1}\end{array}$ & $\begin{array}{r}\text { of } \\
\text { pods }\end{array}$ & $\begin{array}{l}\text { 100-seed } \\
\text { weight } \\
\text { (g) }\end{array}$ & $\begin{array}{l}\text { Seed yield } \\
\left(\mathrm{t} \mathrm{ha}^{-1}\right)\end{array}$ & $\begin{array}{l}\text { Stover } \\
\text { yield } \\
\left.(\mathrm{t} \mathrm{ha})^{-1}\right)\end{array}$ \\
\hline $\mathrm{V}_{1} \mathrm{~T}_{1}$ & $44.07 \mathrm{ab}$ & $2.46 \mathrm{abc}$ & $38.20 \mathrm{~b}$ & & $9.33 \mathrm{a}$ & $1.59 \mathrm{abc}$ & $5.40 \mathrm{ab}$ \\
\hline $\mathrm{V}_{1} \mathrm{~T}_{2}$ & 35.57 cde & $2.50 \mathrm{abc}$ & $38.33 \mathrm{~b}$ & & $9.33 \mathrm{a}$ & 1.44 bcde & $4.90 \mathrm{abc}$ \\
\hline $\mathrm{V}_{1} \mathrm{~T}_{3}$ & $44.33 \mathrm{ab}$ & $2.53 \mathrm{ab}$ & $37.27 \mathrm{~b}$ & & $8.67 \mathrm{ab}$ & 1.35 bcdef & $4.33 \mathrm{bcd}$ \\
\hline $\mathrm{V}_{1} \mathrm{~T}_{4}$ & 33.69 de & $2.27 \mathrm{~d}$ & $23.60 \mathrm{~d}$ & & $8.33 \mathrm{abc}$ & 1.14 ef & 3.90 cde \\
\hline $\mathrm{V}_{2} \mathrm{~T}_{1}$ & $44.41 \mathrm{ab}$ & $2.63 \mathrm{a}$ & $51.33 \mathrm{a}$ & & $7.33 \mathrm{c}$ & $1.82 \mathrm{a}$ & $6.07 \mathrm{a}$ \\
\hline $\mathrm{V}_{2} \mathrm{~T}_{2}$ & $45.67 \mathrm{a}$ & $2.30 \mathrm{~cd}$ & $27.00 \mathrm{~cd}$ & & $8.00 \mathrm{bc}$ & $1.22 \mathrm{def}$ & $3.40 \mathrm{de}$ \\
\hline $\begin{array}{l}\mathrm{V}_{2} \mathrm{~T}_{3} \\
\mathrm{~V}_{2} \mathrm{~T}_{4}\end{array}$ & $\begin{array}{l}38.82 \text { bcd } \\
40.61 \text { abc }\end{array}$ & $\begin{array}{l}2.47 \mathrm{abcd} \\
2.53 \mathrm{ab}\end{array}$ & $\begin{array}{l}42.80 \mathrm{ab} \\
43.13 \mathrm{ab}\end{array}$ & & $\begin{array}{l}7.33 \mathrm{bc} \\
8.00 \mathrm{bc}\end{array}$ & $\begin{array}{l}1.49 \mathrm{abcd} \\
1.62 \mathrm{ab}\end{array}$ & $\begin{array}{l}4.73 \mathrm{bc} \\
4.73 \mathrm{bc}\end{array}$ \\
\hline $\begin{array}{l}V_{3} T_{1} \\
V_{3} T_{2} \\
V_{3} T_{3} \\
V_{3} T_{4}\end{array}$ & $\begin{array}{l}44.04 \mathrm{ab} \\
42.75 \mathrm{ab} \\
39.97 \mathrm{abc} \\
33.58 \mathrm{e}\end{array}$ & $\begin{array}{l}2.50 \mathrm{abc} \\
2.33 \mathrm{bcd} \\
2.50 \mathrm{abc} \\
2.43 \mathrm{abcd}\end{array}$ & $\begin{array}{l}27.13 \mathrm{~cd} \\
41.40 \mathrm{~b} \\
28.00 \mathrm{~cd} \\
34.33 \mathrm{bc}\end{array}$ & & $\begin{array}{l}7.33 \mathrm{bc} \\
8.00 \mathrm{abc} \\
7.33 \mathrm{bc} \\
7.00 \mathrm{c}\end{array}$ & $\begin{array}{l}1.13 \text { ef } \\
1.51 \text { abcd } \\
1.27 \text { cdef } \\
1.02 \mathrm{f}\end{array}$ & $\begin{array}{l}3.13 \mathrm{de} \\
4.87 \mathrm{abc} \\
3.60 \mathrm{cde} \\
2.87 \mathrm{e}\end{array}$ \\
\hline $\begin{array}{l}\mathrm{LSD}^{(0.05)} \\
\mathrm{CV}(\%)\end{array}$ & $3.82^{5.49}$ & $\begin{array}{l}0.19 \\
9.57 \\
\end{array}$ & $8.20^{6.22}$ & & $\begin{array}{r}1.18 \\
14.41\end{array}$ & $\begin{array}{c}0.91 \\
2.15\end{array}$ & $\begin{array}{r}1.15 \\
12.67\end{array}$ \\
\hline
\end{tabular}

Common letters do not differ significantly by Duncan's Multiple Range Test at $5 \%$ level of significance

$\mathrm{T}_{1}$ : 25-30-45-10-1.0-1.0 kgha $^{-1}$ N-P-K-S-Zn-B (Soil test based fertilizer)), $\mathrm{T}_{2}$ : 30-40-60-12-2.01.0 kgha $^{-1}$ N-P-K-S-Zn-B (Fertilizer recommendation guide, 2012) $T_{3}: 40-20-15-0-0-0$ kgha ${ }^{-1}$ $\mathrm{N}-\mathrm{P}-\mathrm{K}-\mathrm{S}-\mathrm{Zn}-\mathrm{B}$ (Farmers practices) and $\mathrm{T}_{4}$ : native fertility (control)

\section{Seed yield}

Table 2 showed that the highest seed yield $\left(1.86 \mathrm{t} \mathrm{ha}^{-1}\right)$ was recorded from BARI Soybean 6 but at par to BARI Soybean 5 and the lowest fromBinasoybean-3. In case of fertilizer treatment where $T_{1}$ gave significantly highest seed yield and the lowest seed yield $\left(1.65 \mathrm{t} \mathrm{ha}^{-1}\right)$ from $\mathrm{T}_{4}$. Interaction effect of variety and fertilizer dose showed that the maximum seed yield $(1.82 \mathrm{t}$ $\left.h^{-1}\right)$ was recorded from $V_{2} T_{1}$ and the lowest seed yield $\left(1.02 \mathrm{t} \mathrm{ha}^{-1}\right)$ from $\mathrm{V}_{3} \mathrm{~T}_{4}$. The result was supported by the findings of Paikera and Mishra (1989).

\section{Stover yield}

Significant effect was found in variety where highest stover yield was recorded from BARI Soybean 6 (Table 2). In fertilizer treatment, showed that the highest stover yield $\left(5.28 \mathrm{t} \mathrm{ha}^{-1}\right)$ was recorded from $\mathrm{T}_{2}$ and the lowest stover yield $(3.08$ $\mathrm{t} \mathrm{ha}^{-1}$ ) from $\mathrm{T}_{4}$ In case of interaction effect of variety and fertilizer dose, the highest stover yield (6.07 $\left.t h^{-1}\right)$ was recorded from $V_{2} T_{1}$ and the lowest stover yield $\left(2.87 \mathrm{t} \mathrm{ha}^{-1}\right)$ from $\mathrm{V}_{3} \mathrm{~T}_{4}$. Tomar and Khajanji (2009) reported that recommended dose of fertilizer $\left(20 \mathrm{~kg} \mathrm{~N}+60 \mathrm{~kg} \mathrm{P}_{2} \mathrm{O}_{5}+20 \mathrm{~kg} \mathrm{~K} \mathrm{~K}_{2} \mathrm{O} / \mathrm{ha}\right)$ recorded significantly higher stover yields of soybean as compared with control and $50 \%$ recommended dose of fertilizer. 


\section{Conclusion}

It could be concluded from the study that STB based fertilizer doses (25-30-4510-1.0-1.0 kg ha ${ }^{-1}$ N-P-K-S-Zn-B ), and soybean var. BARI soybean 6 are superior to the others fertilizer management packages in respect of seed yield and other characters.

\section{Acknowledgement}

The authors avail the opportunity to express their sincere thanks and heartfelt gratitude to the Government of the People's Republic of Bangladesh through its Ministry of Science and Technology (MoST) for providing financial support for conducting field experiment and preparation of the thesis for awarding MS degree in Agronomy, Patuakhali Science and Technology University.

\section{References}

Adu-Dapaah, H.K., B. Asafo-Adjei, M. Owusu-Akyaw, and S. Amoah, 2004. Sustainable Soybean Production in Ghana. Paper presented at a Radio program on soybean in Ghana.

Chowdhury, M.M.U., M.J.U. Sarker, A.K. Choudhury, I.S.M. Farhad, S.K. Bhowal and K.M. F. Hossain. 2013. Soybean cultivation in coastal area of Noakhali. On-Farm Research Division, Bangladesh Agri. Research Institute, Gazipur, Bangladesh. p.1.

Fehr, W.R. 1989. Soybean, importance and distribution.pp.283-300. In: Robblen, G.R.K. Downy and Ashri (ed). Oilcrops of the World.Mc-Graw-Hill.Pub.Com. New York.

Hasio, T.C., E. Acevedo, E. Fereres and W.D. Henderson. 1976. Phil. R. Soc. Bot. 273: 275-500.

Karte, L.L., J.E. Spetch, J.H. Williams and R.C. Sorensen. 1983. Fertilizer of soybean genotypes during reproduction ontogeny I. Agronomic responses. Crop Sci. 23(3): 521-527.

Paikera, A. and S.N. Mishra. 1989. A note on effect of varying levels of nitrogen and phosphorus on yield attributes and yield of soybean. Department of Agronomy, Orissa University of Agriculture and Technology, Bhubaneswar, 751003, India. Orissa J. Agril. Res. 2(1): 68-69.

Singh, D. and V. Singh. 1995. Effect of potassium, zinc and sulphur on growth characters, yield attributes and yield of soybean (Glycine max). Indian J. Agron. 40(2): 223-227.

Tomar, G.S., S.N. Khajanji. 2009. Effect of organic manuring and mineral fertilizer on the growth, yield and economics of soybean (Glycine max (L.) Merrill). Intl. J. Agri. Sci. 5(2): 590-594. 